\title{
Comparative analysis of disaster information website based on web usability evaluation and quality content of disaster information
}

\author{
Indra Agus Riyanto ${ }^{1}$, Ratri Abdatush Sholihah ${ }^{2}$, and Ahmad Cahyadi ${ }^{3}$ \\ ${ }^{1}$ Master Program on Planning and Management of Coastal Area and Watershed, Faculty of Geography, Universitas Gadjah Mada, \\ Indonesia \\ ${ }^{2}$ Computer Science, Computer Science and Electronics Department, Universitas Gadjah Mada, Indonesia \\ ${ }^{3}$ Environmental Geography Department, Universitas Gadjah Mada, Indonesia
}

\begin{abstract}
Disaster is one of the most important researches because every country in the world has their own disaster potential. Disaster assessment improves over time due to technological and information advancements; and it is very reliant to a long period of data record. Disaster information is already available online in various websites, and is presented in form of map, data, video and multimedia contents. Each country has different disaster information standards, the Web Usability and quality of disaster-related content. This research objective is to find good model WEBUSE and quality content both national and international disaster website. National disaster website includes: Geospatial Information Agency (Badan Informasi Geospasial/BIG), Meteorological, Climatological and Geophysical Agency (Badan Meteorologi Klimatologi dan Geofisika/BMKG), National Disaster Management Authority (Badan Nasional Penanggulangan Bencana/BNPB); while international website includes: National Oceanic and Atmospheric Administration (NOAA) and United States Geological Survey (USGS). Usability comparison method uses the WEBUSE questionnaire with 4 categories, content organization and readability, navigation and links, user interface design, and performance and effectiveness; while the disaster-related content quality is measured using scoring method, with 4 categories, the geospatial information, data quality, product, and accessibility, according to United Nations Office for Disaster Risk Reduction (UNISDR). The usability level analysis for all 5 websites are classified as "good", with USGS achieving the highest score of 0.703 . As for the disaster-related quality content analysis result, USGS fulfills all categories.
\end{abstract}

\section{Background}

The existence of disaster-related information is crucial in terms of disaster management, which is now readily accessible through websites as the result of technological advancements. Nevertheless, there are still room for improvement regarding the disaster information, either the quality of the website and content, and the data presented in the website. Disaster information became one of the most important items in disaster management stages [1]. The final result of disaster management is in form of policy to reduce disaster risk on a region [2-3].

Currently, both web and content quality standard in Indonesia needs to be improved, due to the recent nature of web development and disaster data collection. There's also another issue of disaster-related regulation being signed on 2007, which results in all development regarding disaster-related data collection system to be built after 2007, either by BIG or BNPB. The only exception is BMKG which already collects hydro meteorology data before the regulation was signed [4].

All of this issue results in the low standard of disasterrelated website and its contents. One important component is the availability of long-term disaster data record, which would help analyze disaster return period, disaster modelling, and development of various maps, such as susceptibility map, vulnerability map, hazard map, risk map, coping capacity and disaster management [5-6]. Therefore, a comparative test for standard of disaster-related website and its contents, between Indonesia and other country is needed. Web standard comparison is done with usability method using the Website Usability Evaluation [7-9] and the content quality test about the availability and standard of disaster information [10]. The selection of the international website of the USGS and NOAA, and national website $\mathrm{BNPB}, \mathrm{BPBD}$, and BMKG because most web agencies and often used for college learning materials and work practices at the Faculty of Geography, especially in the disaster management.

The benefits of information provisioning and collection of various disaster data depends on its uses. Every disaster data such as volcanic eruptions, floods, landslides, tsunami, earthquakes, sea level rise, and storm, has an important role in disaster management. Volcanic eruption data is important to determine the eruption

\footnotetext{
Corresponding author: indra.agus.r@gmail.com
} 
tendency pattern and return period (Volcanic Explosivity Index /VEI) [11-12]. Flood data is important to determine flood return period and flood modelling [13-14]. Landslide data is needed to develop susceptibility map, landslide model prediction and landslide pattern [15-16]. Tsunami data is needed for reconstruction, tsunami return period, and tsunami scenario modelling [17-18]. Sea level rise data is important to understand the pattern in sea level rise and prediction model of sea level rise [19-20]. Earthquake data is used to analyze earthquake return period and earthquake vulnerability model scenario [2122]. Storm data is important for analyzing the storm return period and predicting the storm model [23-24].

\section{Research method}

\subsection{Tools and materials}

Tools used in this research are Microsoft excel, Google Docs, website traffic statistics. Microsoft Excel is used to input, process, and present the results of the content analysis and WEBUSE, Google Docs is used for charging and distribution of questionnaire online, and website traffic statistics is used to analyze the access visits website of disaster. The materials used in this research in websites of BIG, BMKG, BNPB, NOAA, USGS for WEBUSE and content quality analysis and guidance book the United Nations Office for Disaster Risk Reduction (UNISDR) as a reference for the analysis of content quality.

\subsection{Usability evaluation}

This research uses WEBUSE for the website usability analysis. Web Usability Evaluation Tools (WEBUSE) is a series of questionnaire to determine the usability level and is usable for all kinds of websites [7]. WEBUSE questionnaire contains 4 categories, content, organization and readability; navigation and links; user interface design; performance and effectiveness [7]. Each WEBUSE category has 6 aspects to assess the usability level of websites. Likert scale is used to calculate the usability level. They are strongly disagree $(0.00)$, disagree $(0.25)$, neutral $(0.50)$, agree $(0.75)$ and strongly agree (1.00).

The calculation point each category usability obtained from equation 1 and the results of calculations Overall score for each category based on the equation 2 . The results of the calculation of the overall point usability categories then classified into five classes and compared to the all web.. The usability level are bad, poor, moderate, good and excellent [7] shown in Table 1. The results of the comparative classification of usability becomes important reference in website development.

$x=[\square$ (weight each question of the category) $] /$ [number

$$
\text { of category] }
$$

$x=[\square$ (Overall score for each category) $] /$ [number of

$$
\text { category] }
$$

Data collection in this research is done by survey through questionnaire to 45 respondents, with backgrounds in geography. The details of the respondent consists of 5 lectures, 5 master students, 15 bachelor students, and 20 undergraduate students. The number of respondents taken exceeds that done [7,25] 40 respondents and is eligible to be analyzed. Respondents filled the questionnaire after visiting the websites listed, they are:

1. BIG http://www.big.go.id/,

2. BMKG https://www.bmkg.go.id/,

3. BNPB https://bnpb.go.id/,

4. NOAA http://www.noaa.gov/,

5. USGS https://www.usgs.gov/.

Table 1. Usability Points and Corresponding Usability Levels.

\begin{tabular}{|c|c|c|c|c|c|}
\hline Points, $\mathrm{x}$ & $\begin{array}{c}\mathbf{0} \\
\leq \mathrm{x} \leq \\
\mathbf{0 . 2}\end{array}$ & $\begin{array}{c}\mathbf{0 . 2} \\
<\mathrm{x} \leq \\
\mathbf{0 . 4}\end{array}$ & $\begin{array}{c}\mathbf{0 . 4} \\
<\mathrm{x} \leq \\
\mathbf{0 . 6}\end{array}$ & $\begin{array}{c}\mathbf{0 . 6} \\
<\mathrm{x} \leq \\
\mathbf{0 . 8}\end{array}$ & $\begin{array}{c}\mathbf{0 . 8} \\
\leq \mathrm{x} \leq \\
\mathbf{1 . 0}\end{array}$ \\
\hline $\begin{array}{c}\text { Usability } \\
\text { level }\end{array}$ & Bad & Poor & Moderate & Good & Excellent \\
\hline
\end{tabular}

\subsection{Content analysis}

Disaster-related content and information quality analysis is done through scoring method, with 4 categories as described and detailed by the UNISDR standard [10], they are: geospatial information, data quality, product, and information accessibility. The detailed breakdown of 40 categories is shown at Table 7-11, with 1 score for each parameter. Data quality assessment is done by comparing the 5 websites based on these 40 parameters, and the result is used to determine the disaster-related information quality on all 5 websites. The calculation point each category quality content obtained from equation 1 and the results of calculations Overall score for each category quality content based on the equation 2 .

\section{Results and discussions}

Each WEBUSE category has 6 aspects used to evaluate the usability of a website. The results on the Category of content organization and readability (Table 2) overall with the highest value CON 1, 2, 3, and 6 are USGS whereas CON 4 and 5 BNPB. The high value of the CON 1 because the USGS provides update information and accuracy of information compared to other websites updated and accurate information have an impact on improving the web visitor [26]. BNPB on CON 4 and 5 the highest because of the ease in language Indonesian and English language options provide convenience for users to access the web so as to have an impact on improving the web visitor [27].

Results in the Category of navigation and links (Table 3 ) the highest USGS except in NAV 1 and 3 NOAA. Results in the Category of user interface design (table 4) the highest USE 2, 3, 4, 5 is USGS and NOAA in USE 1 and 6. Results in the Category of user interface design 
(table 4) highest USE 2, 3, 4, 5 is USGS and NOAA in USE 1 and 6 .

The results of the Category of performance and effectiveness (table 5) highest on a PER 1, 2, 4, 5, 6 is the USGS and PER 3 is BNPB. Based on the average comparison of usability score on Table 6 , all 5 websites are classified as having "good" usability. USGS website scores the highest on all categories. NOAA, BNPB and BMKG websites takes the following places, with fluctuating score. BIG website scores the lowest on all categories.

Table 2. Points of content, organisation and readability category.

\begin{tabular}{|c|c|c|c|c|c|}
\hline $\begin{array}{c}\text { Usability } \\
\text { Aspects }\end{array}$ & BIG & BMKG & BNPB & NOAA & USGS \\
\hline CON1 & 0.628 & 0.744 & 0.700 & 0.772 & 0.817 \\
\hline CON2 & 0.583 & 0.694 & 0.617 & 0.667 & 0.722 \\
\hline CON3 & 0.611 & 0.672 & 0.683 & 0.728 & 0.800 \\
\hline CON4 & 0.639 & 0.717 & 0.772 & 0.644 & 0.611 \\
\hline CON5 & 0.650 & 0.728 & 0.744 & 0.678 & 0.639 \\
\hline CON6 & 0.544 & 0.700 & 0.739 & 0.717 & 0.756 \\
\hline
\end{tabular}

Category of content, organization and readability is shown in Table 2. They are

1. CON1: this website contains most of my interest material and topics and they are up-to-date,

2. CON2: I can easily find what I want at this website,

3. CON3: the content of this website is well organised,

4. CON4: reading content at this website is easy,

5. CON5: I am comfortable and familiar with the language used,

6. CON6: I need not scroll left and right when reading at this website.

Table 3. Points of Navigation and Links Category.

\begin{tabular}{|c|c|c|c|c|c|}
\hline $\begin{array}{c}\text { Usability } \\
\text { Aspects }\end{array}$ & BIG & BMKG & BNPB & NOAA & USGS \\
\hline NAV1 & 0.628 & 0.578 & 0.600 & 0.683 & 0.633 \\
\hline NAV2 & 0.644 & 0.650 & 0.644 & 0.717 & 0.722 \\
\hline NAV3 & 0.639 & 0.689 & 0.683 & 0.706 & 0.706 \\
\hline NAV4 & 0.606 & 0.650 & 0.633 & 0.744 & 0.772 \\
\hline NAV5 & 0.633 & 0.689 & 0.689 & 0.739 & 0.761 \\
\hline NAV6 & 0.622 & 0.656 & 0.689 & 0.700 & 0.750 \\
\hline
\end{tabular}

Category of navigation and links is shown in Table 3.

They are

1. NAV1: I can easily know where I am at this website,

2. NAV2: this website provides useful cues and links for me to get the desired information,

3. NAV3: it is easy to move around at this website by using the links or back button of the browser,

4. NAV4: the links at this website are well maintained and updated,

5. NAV5: the website does not open too many new browser windows when I am moving around,

6. NAV6: placement of links or menu is standard throughout the website and I can easily recognise them.
Table 4. Points of User Interface Design Category.

\begin{tabular}{|c|c|c|c|c|c|}
\hline $\begin{array}{c}\text { Usability } \\
\text { Aspects }\end{array}$ & BIG & BMKG & BNPB & NOAA & USGS \\
\hline USE1 & 0.578 & 0.600 & 0.594 & 0.694 & 0.694 \\
\hline USE2 & 0.656 & 0.694 & 0.722 & 0.744 & 0.778 \\
\hline USE3 & 0.567 & 0.733 & 0.761 & 0.744 & 0.778 \\
\hline USE4 & 0.622 & 0.700 & 0.706 & 0.744 & 0.750 \\
\hline USE5 & 0.656 & 0.739 & 0.794 & 0.767 & 0.817 \\
\hline USE6 & 0.639 & 0.667 & 0.689 & 0.717 & 0.706 \\
\hline
\end{tabular}

Category of user interface design is shown in Table 4. They are

1. USE1: this website's interface design is attractive,

2. USE2: I am comfortable with the colours used at this website,

3. USE3: this website contains no feature that irritates me such as scrolling or blinking text and looping animations,

4. USE4: this website has a consistent feel and look,

5. USE5: this website does not contain too many Web advertisements,

6. USE6: the design of the website makes sense and it is easy to learn how to use it.

Table 5. Points of Performance and Effectiveness Category.

\begin{tabular}{|c|c|c|c|c|c|}
\hline $\begin{array}{c}\text { Usability } \\
\text { Aspects }\end{array}$ & BIG & BMKG & BNPB & NOAA & USGS \\
\hline PER1 & 0.517 & 0.517 & 0.478 & 0.472 & 0.511 \\
\hline PER2 & 0.456 & 0.506 & 0.461 & 0.511 & 0.528 \\
\hline PER3 & 0.606 & 0.639 & 0.706 & 0.672 & 0.700 \\
\hline PER4 & 0.550 & 0.611 & 0.600 & 0.633 & 0.644 \\
\hline PER5 & 0.594 & 0.622 & 0.656 & 0.650 & 0.689 \\
\hline PER6 & 0.583 & 0.594 & 0.583 & 0.628 & 0.639 \\
\hline
\end{tabular}

Category of performance and effectiveness is shown in Table 5. They are

1. PER1: I need not wait too long to download a file or open a page,

2. PER2: I can easily distinguish between visited and not-visited links,

3. PER3: I can access this website most of the time,

4. PER4: this website responds to my actions as expected,

5. PER5: it is efficient to use this website,

6. PER6: this website always provides clear and useful messages when I don't know how to proceed.

Table 6. Average Points of Usability Categories.

\begin{tabular}{|c|c|c|c|c|c|}
\hline Category & BIG & BMKG & BNPB & NOAA & USGS \\
\hline CON & 0.609 & 0.709 & 0.709 & 0.701 & 0.724 \\
\hline NAV & 0.629 & 0.652 & 0.655 & 0.715 & 0.724 \\
\hline USE & 0.619 & 0.689 & 0.711 & 0.739 & 0.744 \\
\hline PER & 0.551 & 0.581 & 0.581 & 0.594 & 0.619 \\
\hline Average & 0.602 & 0.658 & 0.664 & 0.687 & 0.703 \\
\hline $\begin{array}{c}\text { Usability } \\
\text { level }\end{array}$ & Good & Good & Good & Good & Good \\
\hline
\end{tabular}


Table 6 shows that the content, organization and readability category have the highest score among other categories. All five websites present their content in an organized manner and is easily read by the visitors. They also displayed a nice and easy-to-navigate user interface design, placing the user interface category at the second place, the increased ease of navigation affects the increase in website visitors [28,29]. As for navigation and links category, BIG, BMKG and BNPB need to improve this part on their respective websites. This is to help the user navigate easier on their website $[30,31]$. The performance and effectiveness category have the lowest score. This shows that all five websites need to improve their respective website performance and effectiveness [25,32].

Table 7. Comparison of Disaster Information Website Based on Geospatial Information Category.

\begin{tabular}{|c|c|c|c|c|c|}
\hline Category & BIG & BMKG & BNPB & NOAA & USGS \\
\hline GEO1 & v & v & v & v & v \\
\hline GEO2 & - & - & v & v & v \\
\hline GEO3 & v & v & v & v & v \\
\hline GEO4 & - & - & v & - & v \\
\hline GEO5 & v & v & v & v & v \\
\hline GEO6 & v & v & v & v & v \\
\hline GEO7 & v & v & v & v & v \\
\hline GEO8 & v & v & v & v & v \\
\hline GEO9 & v & v & v & v & v \\
\hline GEO10 & v & v & v & v & v \\
\hline
\end{tabular}

Category of geospatial information is shown in Table 7 . They are

1. GEO1: contains directional component,

2. GEO2: contains total victim component,

3. GEO3: contains depth component,

4. GEO4: contains damage component,

5. GEO5: contains acreage component,

6. GEO6: contains magnitude component,

7. GEO7: contains geospatial information of longitude and latitude coordinates,

8. GEO8: contains geospatial information of administration location,

9. GEO9: contains geospatial information of damage acreage,

10. GEO10: contains geospatial information of multi hazard.

Table 8. Comparison of Disaster Information Website Based on Accessibility Category.

\begin{tabular}{|c|c|c|c|c|c|}
\hline Category & BIG & BMKG & BNPB & NOAA & USGS \\
\hline ACC 1 & v & v & v & v & v \\
\hline ACC 2 & v & v & v & v & v \\
\hline ACC 3 & v & v & v & v & v \\
\hline ACC 4 & v & v & v & v & v \\
\hline ACC 5 & v & v & v & v & v \\
\hline ACC6 6 & - & v & v & v & v \\
\hline ACC 7 & - & - & - & v & v \\
\hline
\end{tabular}

Category of accessibility is shown in Table 8 . They are

1. ACC1: can be accessed through personal computer,
2. ACC2: can be accessed through mobile phones,

3. ACC3: can be accessed anytime,

4. ACC4: have a detailed and clear contact options,

5. ACC5: contains link to other disaster-related websites,

6. ACC6: multi languages,

7. ACC7: high website statistics.

Table 9. Comparison of Disaster Information Website Based on Data Quality Category.

\begin{tabular}{|c|c|c|c|c|c|}
\hline Category & BIG & BMKG & BNPB & NOAA & USGS \\
\hline DAT1 & - & - & - & v & v \\
\hline DAT2 & v & v & v & v & v \\
\hline DAT3 & - & - & - & v & v \\
\hline DAT4 & v & v & v & v & v \\
\hline DAT5 & v & v & v & v & v \\
\hline DAT6 & - & v & - & v & v \\
\hline DAT7 & - & v & - & v & v \\
\hline DAT8 & - & v & - & v & v \\
\hline DAT9 & - & v & - & v & v \\
\hline
\end{tabular}

Category of data quality is shown in Table 9. They are

1. DAT1: international data scope,

2. DAT2: national data scope,

3. DAT3: regional data scope,

4. DAT4: website contains data record in the last 5 years,

5. DAT5: website contains data record in the last 10 years,

6. DAT6: website contains data record in the last 15 years,

7. DAT7: high static website contains data record in the last 20 years,

8. DAT8: website contains data record in the last 25 years,

9. DAT9: website contains data record in the last 30 years.

Table 10. Comparison of Disaster Information Website Based on Product Category.

\begin{tabular}{|c|c|c|c|c|c|}
\hline Category & BIG & BMKG & BNPB & NOAA & USGS \\
\hline PRO1 & v & v & v & v & v \\
\hline PRO2 & v & v & v & v & v \\
\hline PRO3 & v & v & v & v & v \\
\hline PRO4 & v & v & v & v & v \\
\hline PRO5 & v & v & v & v & v \\
\hline PRO6 & - & - & - & v & v \\
\hline PRO7 & v & v & v & v & v \\
\hline PRO8 & v & v & v & v & v \\
\hline PRO9 & v & v & v & v & v \\
\hline PRO10 & v & v & v & v & v \\
\hline PRO11 & v & v & v & v & v \\
\hline
\end{tabular}

Category of product is shown in Table 10. They are

1. PRO1: personal journal management,

2. PRO2: disaster report,

3. PRO3: financial report and total donation,

4. PRO4: regulatory product,

5. PRO5: research publications,

6. PRO6: open-source software,

7. PRO7: free statistics data, 
8. PRO8: books,

9. PRO9: posters,

10.PRO10: videos,

11.PRO11: free digital map.

Table 11. Comparison of Disaster Information Website Based on Information Update Category.

\begin{tabular}{|c|c|c|c|c|c|}
\hline Category & BIG & BMKG & BNPB & NOAA & USGS \\
\hline INF1 & v & v & v & v & v \\
\hline INF2 & v & v & v & v & v \\
\hline INF3 & v & v & v & v & v \\
\hline
\end{tabular}

Category of information update is shown in Table 11. They are

1. INF1: always updated,

2. INF2: publication through social media (e.g. : Twitter, Facebook, and Instagram),

3. INF3: publication through online news sites.

Quality comparison result from 40 parameters of disaster website content shows variations on each category. Geospatial Information category shows that USGS and BNPB contain all components (Table 7-11). Geospatial category explains about data availability regarding location detail, disaster magnitude, and spatial damage effect. NOAA, BMKG, and BIG doesn't have any data about damage component, and the latter two doesn't have total victim component. BNPB have the authority and responsibility to collect all damage data in Indonesia, and USGS also have similar authority. Accessibility category gives information regarding how easy a website is accessed, links to other websites, and total visitors on that website. Accessibility category analysis result is based on the traffic statistics through Alexa website (www.alexa.com), which shows NOAA at the first place with global ranking of 2.098 and the lowest ranking BNPB at 217.169. The others trailing behind with USGS at 3.254, BMKG at 52.438, and BIG at 143.485.

Table 12. Average of Disaster Information Website Based on All Category.

\begin{tabular}{|c|c|c|c|c|c|}
\hline Category & BIG & BMKG & BNPB & NOAA & USGS \\
\hline GEO & 0.800 & 0.800 & 1.000 & 0.900 & 1.000 \\
\hline ACC & 0.714 & 0.857 & 0.857 & 1.000 & 1.000 \\
\hline DAT & 0.333 & 0.778 & 0.333 & 1.000 & 1.000 \\
\hline PRO & 0.909 & 0.909 & 0.909 & 1.000 & 1.000 \\
\hline INF & 1.000 & 1.000 & 1.000 & 1.000 & 1.000 \\
\hline Average & 0.751 & 0.869 & 0.819 & 0.980 & 1.000 \\
\hline
\end{tabular}

Data quality category gives a detail regarding record data in a certain period and scope of the data. Scope analysis result shows that the USGS and NOAA data has larger scope due to its worldwide coverage, compared to the national coverage of BNPB, BIG, and BMKG. Data record parameter for USGS, NOAA and BMKG shows data record up to 30 years back. BIG and BNPB only contains the last 10 years data due to both website were made back in 2008. The product category gives us a picture of the products generated by the website, either for research, society information, and provided applications. USGS and NOAA scores better in product department due to having open source software for disaster analysis, which can be downloaded and modeled. USGS have 42 software and NOAA have 5 software.

Information Update category tells us about the speed of update and disaster information publication through social media, news sites, and maps. Based on the result, all 5 websites fulfills this requirement (Table 12). But both NOAA and USGS website have a better video publication compared to the other three websites, in terms of explaining disaster information and more detailed and informative disaster animation video. Overall, the USGS website fulfills all the parameters, followed by NOAA. The first rank in Indonesia is the BMKG website, which having an edge on having a longer period of record data compared to BNPB and BIG. As for the content quality, all three $\mathrm{BMKG}, \mathrm{BIG}$, and BNPB need to improve the disaster information quality, especially the disaster software component, record data, and the quality of disaster video animation.

\section{Conclusion}

The result of Web Usability test shows that both USGS and NOAA website scores a good grade, especially their content, organization and readability, and user interface design. They also scored the highest for disaster-related data content quality. All three Indonesian disaster websites need to improve their quality in developing disaster-related software, longer period of record data, and improving the quality of disaster-related video. Finally, all websites needs to improve their performance and effectiveness.

Thanks to all lecturers of Environmental Geography Department, Environmental Geography assistant Universitas Gadjah Mada, Environmental Geography student, class of 2012, 2013, 2014, 2015, 2016, and 2017 for their help in filling the questionnaire.

\section{References}

1. Grothe-Hammer, $\mathrm{M}$ and Berthod, O., Current Sociology, The Programming of Decisions for Disaster and Emergency Response:A Luhmannian Approach, 65, 5, 735-755 (2017)

2. Moe, T.L and Pathranarakul, P., Disaster Prevention and Management, An integrated approach to natural disaster management Public project management and its critical success factors, 15, 3, 396-413 (2013)

3. Huq, S.M. S., European Journal of Research in Social Sciences, Community Based Disaster Management Strategy In Bangladesh: Present Status, Future Prospects And Challenges, 4, 2, 22-35 (2016)

4. Law of The Republic of Indonesia, Penanggulangan Bencana, 24 (2007)

5. Intarti,Y.N., Fitrinitia, I.S., Widyanto, M.R., and Simarmata, H.A., International Journal of Disaster Recovery and Business Continuity, Towards Disaster Management in Indonesia Case Studies: Jakarta and Yogyakarta Provinces, 4, 11-22 (2013) 
6. Stringfellow, P., Australasian Journal of Construction Economics and Building, Construction Contractors Involvement in Disaster Management Planning, 14, 2, 120-132 (2014)

7. Chiew, T.K and Salim, S.S., Malaysian Journal of Computer Science, WEBUSE: Website Usability Evaluation Tool, 16, 1, 47-57 (2003)

8. Fajri, A., Ariyanti, M.A., and Zuliestiana, D.A., eProceeding of Management, Comparative Analyze on Website Quality Online Travel Agencies Traveloka and Tiket.com Based on Customer Perceptions, 3, 2, 1-8 (2016)

9. Rohmah, L.F., Aryadita, H., and Mursityo, Y.T., Jurnal Pengembangan Teknologi Informasi dan Ilmu Komputer, Analisis Perbandingan Website Toko Buku Online Menggunakan Website Usability Evaluation Tool Studi Kasus pada Bukukita dan Tokopedia, 2, 8, 2604-2613 (2018)

10. UNISDR, National Disaster Risk Assessment Governance System, Methodologies, and Use of Results (2017)

11. Lee, D.S and Mackenzie, A.R., International Journal Climatol, Trans-Hemispheric Effect of Large Volcanic Eruptions as Recorded by an early 19th Century Diary, 30, 2217-2228 (2010)

12. Brown, S.K., Crosweller, H.S., Stephen, R., Sparks, J., Contrell, E., Deligne, N.I., Guerrero, N.O., Hobbs, L., Kiyosugi, K., Loughlin, S.C., Slebert, L., and Takarada, S., Journal of Applied Volcanology, Characterisation of the Quaternary eruption record: analysis of the Large Magnitude Explosive Volcanic Eruptions (LaMEVE) Database, 3, 5, 1-22 (2014)

13. Hapsari, R.I and Zenurianto, M., American Journal of Engineering Research (AJER), View of Flood Disaster Management in Indonesia and the Key Solutions, 5, 3, 140-151 (2016)

14. Brouwer, T., Eliander, D., Loenen, A.V., Booij, M.J., Wijnberg, K.M., Verkade, J.S., and Wagemaker, J., Nat. Hazards Earth Syst. Sci., Probabilistic Flood Extent Estimates from Social Media Flood Observation, 17, 735-747 (2017)

15. Sartohadi, J., Samodra, G., and Hadmoko, D.S., International Journal of Geoinformatics, Landslide Susceptibility Assessment using Heuristic Statistically Method in Kayangan Catchment Kulonprogo Yogyakarta-Indonesia, 6, 3, 23-28 (2010)

16. Othman, A.N., Mohd, W.M.N.W., and Noraini, S., 8th International Symposium of the Digital Earth (ISDE8) IOP Conf. Series: Earth and Environmental Science 18, Accuracy Assessment of Landslide Prediction Models (2014)

17. Suppasri, A., Fukutani, Y., Abe, Y., and Imamura, F., Report of Tsunami Engineering, Relationship between Earthquake Magnitude and Tsunami Height along the Tohoku Coast based on Historical Tsunami Trace Database and the 2011 Great East Japan Tsunami, 3, 37-49 (2013)
18. Ishimura, D., Geosci. Lett, Re-examination of the Age of Historical and Paleo-Tsunami Deposits at Koyadori on the Sanriku Coast, Northeast Japan, 4, 11 (2017)

19. Kemp, A.C., Dutton, A., and Raymo, M.E., Curr Clim Change Rep, Paleo Constraints on Future SeaLevel Rise, 1, 205-215 (2015)

20. Marfai, M.A.; Sekaranom, A.B.; Cahyadi, A., Arabian Journal of Geosciences, Profiles of Marine Notches in The Baron Coastal Area - Indonesia, 8, 1, 307-314 (2015)

21. Talebi, M., Zare, M., Madahi-Zadeh, R., and BaliLashak, A., Turkish Journal Earth Science, SpatialTemporal Analysis of Seismicity before the 2012 Varzeghan, Iran, Mw 6.5 Earthquake, 24, 289-301 (2015)

22. Marc, O., Meunier, P., and Hovius, N., National Hazards Earth System Science, Prediction of the area Affected by Earthquake-induced landsliding based on Seismological Parameters, 17, 1159-1175 (2017)

23. Scott, P., Eastin., M.D., and Garcia, W.J., GSA Today, The Geological Legacy of Hurricane Irene:Implications for the Fidelity of the Paleo-Storm Record, 23, 12, 4-10 (2013)

24. Ferreira, C.M., Oliveira, F., and Irish, J.L., Journal of The American Water Resources Association, Arc Stormsurge: Integrating Hurricane Storm Surge Modeling And Gis, 50, 1, 219-233 (2014)

25. Vatankhan, N., Wei., K.T., and Letchmunan, S, International Journal of Software and its Applications, Usability Measurement of Malaysia Online Tourism website, 8, 12, 1-18 (2014)

26. Al-Manasra, E.A., Khair, M., Zaid, S.A., and TaherQutaishaf, F, Arabic Economic and Business Journal, Investigating the Impact of Website Quality on Costumers' Satisfaction in Jordanian Telecomunication Sector, 8, 31-37 (2013)

27. Roy, S., Pattnaik, P.K., and Mall, R, Egyptian Informatics Journal, A Quantitative Approach to Evaluate Usability of Academic Website Based on Human Perception, 15, 159-167 (2014)

28. Mustafa, S.H and Al-Zoua'bi, L.F, In: International Arab Conference on Information Technology, Tunisia, Usability of the Academic Website of Jordan Universities An Evaluation Study, 1-9 (2008)

29. Hussain, A., Mkpojigu, O.C., Jamaludin, N.H., and Moh, S.T.L, In: The $2^{\text {nd }}$ International Conference on Applied Science and Technology, A Usability Evaluation of Lazada Mobile Application, 1-6 (2017)

30. Hasan, L. and Abuelrub, E, Applied Computing and Informatics, Assessing the Quality of Web Sites, 9, 11-29 (2011)

31. Lestari, D.M., Hardianto, D., and Hidayanto, N, International Journal of Software Engineering and its Applications, Analysis of User Experience Quality on Responsive Web Design from its Informative Perspective, 8, 5, 53-82 (2014) 
32. Abdullah, R and Wei, K.T, International Journal of Computer Science and Network Security, Usability Measurement of Malaysia Online News Website, 8, 5, 159-166 (2008) 